\title{
OS KAINGANG DA TERRA INDÍGENA FAXINAL: A CONFIGURAÇÃO ATUAL DAS PRÁTICAS SOCIOCULTURAIS TERRITORIAIS
}

\author{
Juliano Strachulski \\ Doutor em Geografia pelo Programa de Pós-Graduação em Geografia - UEPG \\ julianomundogeo@gmail.com \\ Adnilson de Almeida Silva \\ Professor Doutor do Programa de Pós-Graduação em Geografia - UNIR \\ adnilson@unir.br \\ Nicolas Floriani \\ Professor Doutor do Programa de Pós-Graduação em Geografia - UEPG \\ florianico@gmail.com \\ Jorge No Kaya Alves \\ Professor indígena - SEED/PR \\ nokaya jorge@hotmail.com
}

\begin{abstract}
RESUMO
A proposta do artigo é compreender e apresentar a relação entre as práticas socioculturais territoriais atuais dos Kaingang da Terra Indígena Faxinal, localizada no município de Cândido de Abreu-PR. Este povo sofreu perdas territoriais, o que implicou na diminuição da intensidade de algumas de suas práticas tradicionais. Outras permanecem, como a língua e a organização social baseada na divisão em metades exogâmicas: Kamẽ e Kanhru. Contudo, o contato intenso também propicia uma hibridização de práticas (existência concomitante da agricultura tradicional e moderna). Por outro lado, ocorre a invenção de tradições como festas de santos, rezas, bailes, futebol, dentre outras. A convivência com o não-indígena provocou descontinuidades, mas também permanências, ressignificações, hibridizações e (re)invenções a partir do contato com o outro e dos processos de absorção e resistência.
\end{abstract}

Palavras-chave: Permanência. Ressignificação. Hibridismo. (RE)invenção de tradição.

\section{THE KAINGANG OF TERRA INDÍGENA FAXINAL: THE CURRENT CONFIGURATION OF TERRITORIAL SOCIO-CULTURAL PRACTICES}

\begin{abstract}
The proposal of article is understand and present the relationship between current territorial socio-cultural practices of Kaingang of Terra Indígena Faxinal, located in the municipality of Cândido de Abreu-PR. This people suffered territorial losses, which implied in reducing intensity of some its traditional practices. Others remain, such as language and social organization based on the division in exogamous halves: Kamẽ and Kanhru. However, intense contact also provides a hybridization of practices (concomitant existence of traditional and modern agriculture). On other hand, there is the invention of traditions as feasts of saints, prayers, dances, football, among others. The coexistence with the nonindigenous caused discontinuities, but also permanences, resignification, hybridizations and (re)inventions from the contact with the other and processes of absorption and resistance.
\end{abstract}

Keywords: Permanence. Resignification. Hybridity. (RE)invention of tradition.

\section{INTRODUÇÃO}

A cultura Kaingang desenvolveu-se na floresta com Araucárias, em territórios do Paraná, Rio Grande do Sul, Santa Catarina e São Paulo (TOMMASINO, 2002). Porém, seu modo de vida sob os pinheirais começou a se transformar, a partir do contato com os europeus, no início do século XVI.

$\begin{array}{llllll}\text { Caminhos de Geografia } & \text { Uberlândia - MG } & \text { v. 19, n. } 68 & \text { Dez/2018 } & \text { p. 307-325 } & \text { Página } 307\end{array}$


Em meados do século XIX inicia-se a intensificação da relação entre práticas culturais Kaingang e da sociedade não-indígena, as quais remetem às condições encontradas na atualidade, marcadas pela exclusão e invisibilidade. Neste sentido, a proposta deste texto é compreender a relação entre as práticas socioculturais territoriais atuais dos Kaingang da Terra Indígena Faxinal -TIF, no município de Cândido de Abreu, Estado do Paraná.

Ao longo do tempo e ao largo do espaço os Kaingang da TIF têm passado por um processo de interação intensa com a sociedade não-indígena, de modo que busca se adaptar ao momento socioeconômico e cultural do qual integram, num processo híbrido de apropriação de uma cultura externa, bem como de resistência, no qual ocorrem rupturas, ressignificações, (re)invenção de tradições, além de algumas permanências.

Determinadas características culturais dos Kaingang como a língua materna, permanece viva no cotidiano da TIF, bem como a organização social baseada na divisão em metades exogâmicas Kamẽ e Kanhru. Outras práticas como a pintura corporal, o artesanato e as rodas de chimarrão são ressignificadas, com isso atendem aos estímulos do presente em relação à convivência com o nãoindígena e às novas situações internas.

$\mathrm{Na}$ tentativa de se adaptar a modernidade, mas também reforçar elementos tradicionais, ocorrem processos que promovem a combinação entre elementos modernos e tradicionais simultâneos, os quais se caracterizam como hibridismos. Tal conceito é de importância para entender o processo de interação dos valores tradicionais das pessoas de comunidades rurais com os elementos da modernidade, ou seja, a passagem do meio natural ao meio técnico-científico-informacional, que causa transformações profundas no espaço por meio da instrumentalização e evolução das técnicas e dos objetos (SANTOS, 2008).

Em conformidade com Canclini (2008, p. 29) o hibridismo apresenta maleabilidade em "[...] nomear não só as combinações de elementos étnicos ou religiosos, mas também a de produtos das tecnologias avançadas e processos sociais modernos ou pós-modernos".

Assim, possibilita compreender que localmente há uma agricultura composta tanto por elementos tradicionais, como sementes crioulas, semeadeira manual e roça no toco, bem como semeadeira motomecanizada, o uso de agrotóxicos, com revolvimento do solo e uma medicina igualmente hibrida com o uso de espécies vegetais medicinais em conjunto com medicamentos industrializados.

Complementarmente, para organizar as relações sociais e a cultura local, além do hibridismo, concebem tradições como os bailes com música gaúcha, a festa do dia do índio, a cadeia, o uso de saias com pregas e o jogo de futebol que atraem a atenção da maioria das pessoas da TI Faxinal. São tradições forjadas, pois desenvolveram uma continuidade ao longo do tempo através das repetições, de modo que criou-se o caráter de participar e vivenciar tais atividades (HOBSBAWN e RANGER, 1997).

Sobre esta questão, é afirmado a existência de uma ressignificação, cujo contexto é expressado como uma (re)invenção, conforme avaliam Hobsbawn e Ranger (1997, p. 328): "Grupos sociais, ambientes e contextos sociais inteiramente novos, ou velhos, mas incrivelmente transformados, exigem novos instrumentos que assegurem ou expressem identidade e coesão social, e que estruturem relações sociais".

Ao longo da história recente de transformações culturais aliado a perdas territoriais a que foram submetidos os Kaingang buscam reajustar seu modo de vida, em decorrência de determinadas circunstâncias, as quais prevalecem elementos criados ou modernos e em outras, aqueles de recorrências tradicionais. Os Kaingang da TIF procuram se adaptar a este choque entre perspectivas culturais diferentes e com isso reforçam seus anseios, suas convicções e suas apropriações de mundo.

Essa condição de mudanças e permanências é debatido por Almeida Silva $(2010 ; 2015 a)$ como condição à realização dos "marcadores territoriais" - isto é, pela construção e cosmovisão do próprio povo - e dos "demarcadores territoriais" (as transformações e a inserção de outros valores provenientes de culturas e estruturas externas, as quais influenciam e promovem mudanças dentro de um determinado agrupamento humano). 


\section{PRÉVIA REFERENCIALIDADE TEÓRICA}

Ao se tratar com povos originários, também categorizados como indígenas, ameríndios e que alguns autores consideram ainda como povos tradicionais, é necessário que se relacione alguns conceitos que são norteadores no campo da pesquisa. Notadamente, na Geografia, a cultura tem sido um desses conceitos que desde os primórdios da moderna ciência geográfica é utilizado com relevância, especialmente, naquela voltada à parte humana.

Deste modo, é possível a partir das várias abordagens culturais estabelecer parâmetros de análise, no caso específico de nosso estudo temos como referências os estudos feitos por Claval e outros teóricos da Geografia Humanista/Humanística/Nova Geografia Cultural, os quais tem contribuído para o debate que relaciona à dimensão espacial e/ou territorial. Autores como Denis Cosgrove; Roberto Lobato Corrêa; Paulo César da Costa Gomes; Salete Kozel, Maria Geralda de Almeida; Zeny Rosendahl, Sylvio Fausto Gil Filho, Ângelo Serpa, Giuliana Andreotti, Augustin Berque, Éric Dardel, Anne Buttimer, Peter Jackson, James Duncan, Nancy. Duncan, Don Mitchell, Terezinha Fraxe, Álvaro Heidrich, Werther Holzer, Edward Relph, Tereza Barata Salgueiro, Joël Bonnemaison, Oswaldo Bueno Amorim Filho, Yi-Fu Tuan, dentre outros, inserem em seus estudos concepções culturais relacionadas às categorias e conteúdos analíticos geográficos, e percorrem o urbano, rural, religiosidade/espiritualidade, enfim uma gama de possibilidades, em sua maioria ancorada na perspectiva fenomenológica, o que demonstra a pluralidade e a vitalidade da ciência geográfica em atuar nos variados campos de pesquisa.

Por opção nossa, dialogaremos apenas com alguns dos autores acima mencionados. Entendemos que os conhecimentos tradicionais indígenas ou etnoconhecimentos ocorrem a partir do contato entre coletividades humanas com práticas culturais distintas, em que a cultura é na afirmação de Claval (2007, p. 63):

[...] a soma dos comportamentos, dos saberes, das técnicas, dos conhecimentos e dos valores acumulados pelos indivíduos durante suas vidas e, em uma outra escala, pelo conjunto dos grupos de que fazem parte. A cultura é herança transmitida de uma geração a outra. Ela tem suas raízes num passado longínquo, que mergulha no território onde seus mortos são enterrados e onde seus deuses se manifestaram.

Esses saberes ou conhecimentos agregam, por conseguinte, os elementos internos, próprios de uma cultura, além daqueles que surgiram do diálogo com outros povos. Ainda para o autor, a cultura constitui-se como "[...] um dado fundamental na compreensão dos lugares. Ela permite perceber os laços que os indivíduos tecem entre si, sobre a maneira como instituem a sociedade, como a organizam e como a identificam ao território no qual vivem ou com o qual sonham" (CLAVAL, (2007, p. 210). Assim, por haver o intercâmbio como uns dos elementos que compõem a sociabilidade, isso implica em afirmar que a cultura é dinâmica, se dá no espaço/território, o qual é lócus privilegiado das ações humanas, ou o espaço de ação, (CASSIRER, 1968).

$\mathrm{Na}$ explicação do processo como a cultura se desenvolve apoiamo-nos do princípio filosófico defendido por Morin (1997, p. 45), que esboça que a cultura se operacionaliza fragmentadamente e dispersa como peças de um quebra-cabeça, de modo que se realiza em ajustes herméticos, porém articuladamente e reintegra o que estava desarmonizado. Na sua concepção, Morin, compreende que a cultura vai além de uma simples constatação, ela é a policultura, isto é, consiste na somatória de inúmeras experiências e conhecimentos que o ser humano adquire ao longo de sua trajetória no Planeta, com isso afirma que:

A cultura é a junção do que está separado [...] a cultura não é cumulativa, ela é auto organizadora, ela capta as informações principais, seleciona os problemas principais, dispões de princípios de inteligibilidade capazes de desatar nós estratégicos[...] certamente, a cultura só pode ser lacunar e cheia de buracos, inacabada e mutante. Ela deve continuamente integrar o novo ao velho, o velho ao novo (MORIN, 1997, p. 46). 
A partir das afirmações de Claval (2007) e Morin (1997), refletimos sobre o papel do espaço/território/lugar/paisagem e inquirimos: a cultura poderá ser geografada ou se constituir como "marcador territorial"? Conquanto, a resposta pareça simples, é indispensável considerar que a cultura assim como o espaço geográfico transportam em si mesmo suas próprias eficácias e configurações, vez que as ações humanas qualificam, dão formas, sentidos representativos simbólicos e representatividades sociais, as quais são intrínsecas a cada povo ou coletividade humana.

Neste sentido, o conceito de cultura remete à afinidade com que os seres humanos estabelecem com a terra, pois é nela que produz ou extrai os alimentos para sua sobrevivência, ela é o local de seu acolhimento, seu lar, portanto, é também sua geografia, conforme justifica Dardel (2011, p. 48):

[...] a ligação do homem com a terra recebeu, na atmosfera espaço-temporal do mundo mágico-mítico, um sentido essencialmente qualitativo. A geografia é mais do que uma base ou elemento. Ela é um poder. Da terra vêm as forças que atacam ou protegem o homem, que determinam sua existência social e seu próprio comportamento, que se misturam com sua vida orgânica e psíquica, a tal ponto que é impossível separar o mundo exterior dos fatos propriamente humanos.

Concordamos com o autor, visto que consideramos o ser humano, motivado por necessidades a qualificar seu espaço de ação por meio de representações e formas simbólicas e representatividades sociais, as quais integram os "marcadores territoriais" (ALMEIDA SILVA, 2010; 2015a; 2015b), em razão de suas qualidades e competências que resultam na construção da realidade, em que a cultura não é desassociada, tampouco o espaço e o território.

A realidade da construção da espacialidade/territorialidade nos tempos atuais para os povos indígenas são ressignificadas como estratégias, das quais precisam para sobrevivência física, material, imaterial, social e cultural, onde o território é a base para a realização de suas ações. Nesta lógica, Carvalho Melo e Sousa (2015) e Carvalho Melo e Almeida Silva (2016) consideram que o papel desempenhado pelas estratégias antropofágicas por meio de tecnologias utilizadas pelos povos originários consiste na atuação para fortalecer o processo de hibridização ou transculturalização sócio-ambiental-político-territorial com vista à uma autonomia e liberdade coletiva.

Esse fortalecimento híbrido é resultado da aproximação com a sociedade envolvente, no entanto, os etnoconhecimentos biológico e ecológico, inclusive da medicina tradicional, possuem estreita vinculação com a espacialidade/territorialidade, logo com a identidade, a espiritualidade e a cultura, e são apreendidas pela interface com outros conceitos, os quais são caracterizadas por duas dimensões basilares e que podem ocorrer concomitantemente, em conformidade com que pondera Haesbaert (2004, p. 42):

[...], uma dimensão simbólica, cultural, por meio de uma identidade territorial atribuída pelos grupos sociais, como forma de controle simbólico sobre o espaço onde vivem (sendo também, portanto, uma forma de apropriação), e uma dimensão mais concreta, de caráter político-disciplinar: a apropriação e ordenação do espaço como forma de domínio e disciplinarização dos indivíduos.

Essa constatação nos propicia a outras ponderações que são conexas ao entendimento do território, dos valores culturais, dos valores sociais, dos valores espirituais e dos etnoconhecimentos dos povos originários, que desde tempos imemoriais, estabeleceram cosmovisões, percepções e interdependência com o meio em que vivem para adquirirem respostas para a cura de doenças físicas, psicológicas e espirituais (o que inclui aquelas destinadas a ritualísticas), bem como para a realização de sua cultura, de modo que são consideradas como "geossímbolos" (BONNEMAISON, 2002) ou "marcadores territoriais" (ALMEIDA SILVA, 2010; 2015a), os quais são construídos:

[...] a partir dos símbolos que ocorrem enquanto espaço de ação, definem territorialidades vinculadas à cosmogonia e experiências socioespaciais e possibilitam a formação das identidades culturais e do pertencimento identitário. [...] são experiências, vivências, sentidos, sentimentos, percepções, espiritualidade, 
significados, formas, representações simbólicas e presentificações que permitem a qualificação do espaço e do território como dimensão das relações do espaço de ação, imbricados de conteúdos geográficos (ALMEIDA SILVA, 2010, p. 106).

Esta compreensão e apreensão caminha na mesma direção proposta por Robert Sack (1986) ao conceituar a territorialidade como elemento da condição sobre a terra em seu processo de edificação social e territorial, o que nos conduz aos contextos dos modos de vida, do conceber, perceber, do sentir, do viver e do se relacionar consigo mesmo e com outros. Desta maneira, Sack (1986, p. 05; 21) afirma que.

Territorialidade para humanos é compreendida como uma estratégia geográfica poderosa de controle de pessoas e coisas, assim como de áreas. Territórios políticos e propriedade privada da terra podem ser suas formas mais íntimas, mas a territorialidade advêm de graus variados em variados contextos sociais. Seu uso ocorre em relações de cotidianidade e em organizações complexas. Territorialidade se revela como uma expressão geográfica primária de poder social. [...] territorialidade possui uma forma de comunicação. De fato, envolve um marcador ou pode assinar como é achado comumente em um limite. [...] Um limite territorial pode ser a única forma simbólica que combina uma afirmação sobre a direção em espaço e uma confirmação sobre posse ou exclusão.

Ao apresentar a cotidianidade que ocorre no território em nossa análise entendemos que o autor considera como fundamental os elementos e fenômenos que ocorrem na cultura, ainda que essa se distingue não somente como um espaço onde se realiza harmonia, mas também como de disputas, inclusive de narrativas que justificam o exercício de poder e da existência humana, de modo que nos transporta à conceituação, distinção e aproximação de espaço e território, conforme exposto por Bonnemaison (1981, p. 261-262):

Portanto, espaço e território não podem ser dissociados: o espaço é errância, o território é enraizamento. O território tem necessidade de espaço para adquirir o peso e a extensão, sem os quais ele não pode existir; o espaço tem necessidade de território para se tornar humano.

Deste modo, consideramos que identidade, cultura, pertencimento, enraizamento, território, territorialidade, espaço, espacialidade, dentre outros conceitos, apenas são compreendidos associadamente ao reportarmos aos povos originários, visto que em sua concepção e cosmovisão, toda a materialidade e imaterialidade são interdependentes e a ausência de um compromete a existência do outro, o que culmina no apego, no sentimento, no sentido topofílico expresso por Tuan (1980) para as relações vividas pelos seres humanos em seu meio.

\section{MATERIAIS E MÉTODOS}

O desenvolvimento dessa pesquisa contou com trabalhos de campo realizados na TIF entre os meses de abril e junho do ano de 2015, com a realização de três estadias, uma delas com duração de um mês e as demais com permanência de uma semana cada.

A realização dos trabalhos de campo possibilitou compreendermos os processos em curso na TIF, de modo a retratar a relação entre práticas tradicionais e modernas que influenciam a cultura local, a partir das quais os Kaingang traçam suas vidas, tanto ao que se refere às relações sociais, bem como técnicas de trabalho e outras situações do cotidiano.

Em campo, buscou-se em alguns momentos utilizar a técnica de observação simples. Nestes termos, procurava-se uma visão externa ao povo e à situação estudada, de modo a observar espontaneamente os fatos. "Neste procedimento, o pesquisador é muito mais um espectador que um ator" (GIL, 2008, p. 101).

$\begin{array}{llllll}\text { Caminhos de Geografia } & \text { Uberlândia - MG } & \text { v. 19, n. } 68 & \text { Dez/2018 } & \text { p. 307-325 } & \text { Página } 311\end{array}$


Aliado à observação simples dispomos de um caderno de campo, com posterior transferência de informações ao computador. Gil (2008, p. 103) destaca que para melhor compreensão e captação das informações o "[...] registro da observação simples se faz geralmente mediante diários ou cadernos de notas".

Em outros momentos, fazia-se uso da observação participante, técnica que permite uma captação/percepção ativa da realidade, ou seja, a interação de momentos do cotidiana da comunidade. Aqui buscava-se uma aproximação, de modo a inter-relacionar-se com os eventos locais cotidianos (festas, trabalho, reuniões, momentos de reza, caminhadas pela TIF, dentre outros), o que nos levou ao entendimento do processo de vivência apontado por Gil (2008, p. 103), como: "Daí por que se pode definir observação participante como a técnica pela qual se chega ao conhecimento da vida de um grupo a partir do interior dele mesmo".

A partir dessa aproximação, realizamos entrevistas de caráter aberto e não estruturado, conforme esclarece Gil (2008), ou seja, de procurar compreender a relação entre o moderno, o tradicional e outros elementos em jogo na comunidade e na vida das pessoas.

Neste sentido, realizamos entrevistas não-estruturadas ou informais, as quais consistem em propor que o entrevistado fique à vontade e decida como construirá suas respostas, mediante um diálogo, uma situação de interação. Tal técnica é recomendada para "[...] estudos exploratórios [...] ou oferecer visão aproximativa do problema pesquisado" (GIL, 2008, p. 111).

Os diálogos foram promovidos ao ar livre, mas com as temáticas centrais - moderno e tradicional como focos condutores das entrevistas, razão pela qual foram dispensadas a aplicação de questionários. Os entrevistados foram eleitos aleatoriamente, conforme disponibilidade e possibilidade em participar da pesquisa.

De modo complementar, foram feitas observações in loco, o que possibilitou a percepção de fatos cotidianos ou habituais das pessoas (GIL, 2008), além da captação de vários momentos a partir do uso de uma câmera fotográfica, de modo a demonstrar o campo de estudo e a presença de elementos do modo de vida tradicional, moderno e sua interação.

\section{RESULTADOS E DICUSSÕES}

No passado o povo Kaingang possuía vastas áreas territoriais e liberdade para realizar suas práticas tradicionais. Contudo, com o contato, sofreram perdas territoriais expressivas, de maneira que ficaram aprisionados, o que é caracterizado como um processo de desterritorialização, o que teve repercussões negativas em seu modo de vida, tanto cultural, social, espiritual, ambiental e na própria organização do povo.

A área inicial da TIF, a partir das demarcações, era de 19.205 ha, desde a década de 1910, entretanto, devido às pressões externas, o território foi reduzido para 2.785 ha entre as décadas de 1920 e 1930, posteriormente, na década de 1950 houve nova diminuição, a qual permanece na atualidade com 2.043 ha, conforme Mota e Novak (2008), e apresentado na Figura 1. A diminuição das áreas atendeu a interesses da sociedade abrangente, isto é, foram transferidas para companhias colonizadoras e particulares, principalmente, fazendeiros.

O intenso e violento processo de contato entre os povos originários e a sociedade não-indígena, trouxe perda significativa de seus territórios (em torno de 90\%), causou e ainda causa mudanças, rupturas, hibridizações, ressignificações, (re)invenção de tradições, mas também permanências, num processo contínuo, dinâmico e em constante completitude.

Com a realização das entrevistas, dos diálogos estabelecidos e observações em campo foi possível constatar que na TIF são perceptíveis a existência de práticas tradicionais e modernas, imbricadas no cotidiano dos moradores, que se realizam tanto ao convívio social quanto no exercício das práticas produtivas, as quais marcam a vida da população, até mesmo como condição de sobrevivência frente aos desafios que se colocam no contexto da atualidade.

Assim, no território local ocorre um embate entre as relações sociais tradicionais e a introdução de novos elementos, entendidos como modernos. Contudo, ressalta-se que esse choque não deve ser compreendido apenas como uma dicotômica entre visões e posturas entre duas dimensões espaciais/territoriais, que embora antagônicos se complementam, em razão da cultura apresentar-se e ser dinâmica. Tal condição é uma característica que se circunscreve como hibridização ou

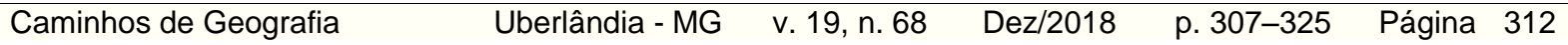


(re)invenção de tradições, conforme avaliam Canclini (2008) e Hobsbawn e Ranger (1997), respectivamente ao analisarem conceitualmente questões relacionadas à trajetória humana.

Figura 1: Mapa de localização da Terra Indígena Faxinal e configuração territorial atual

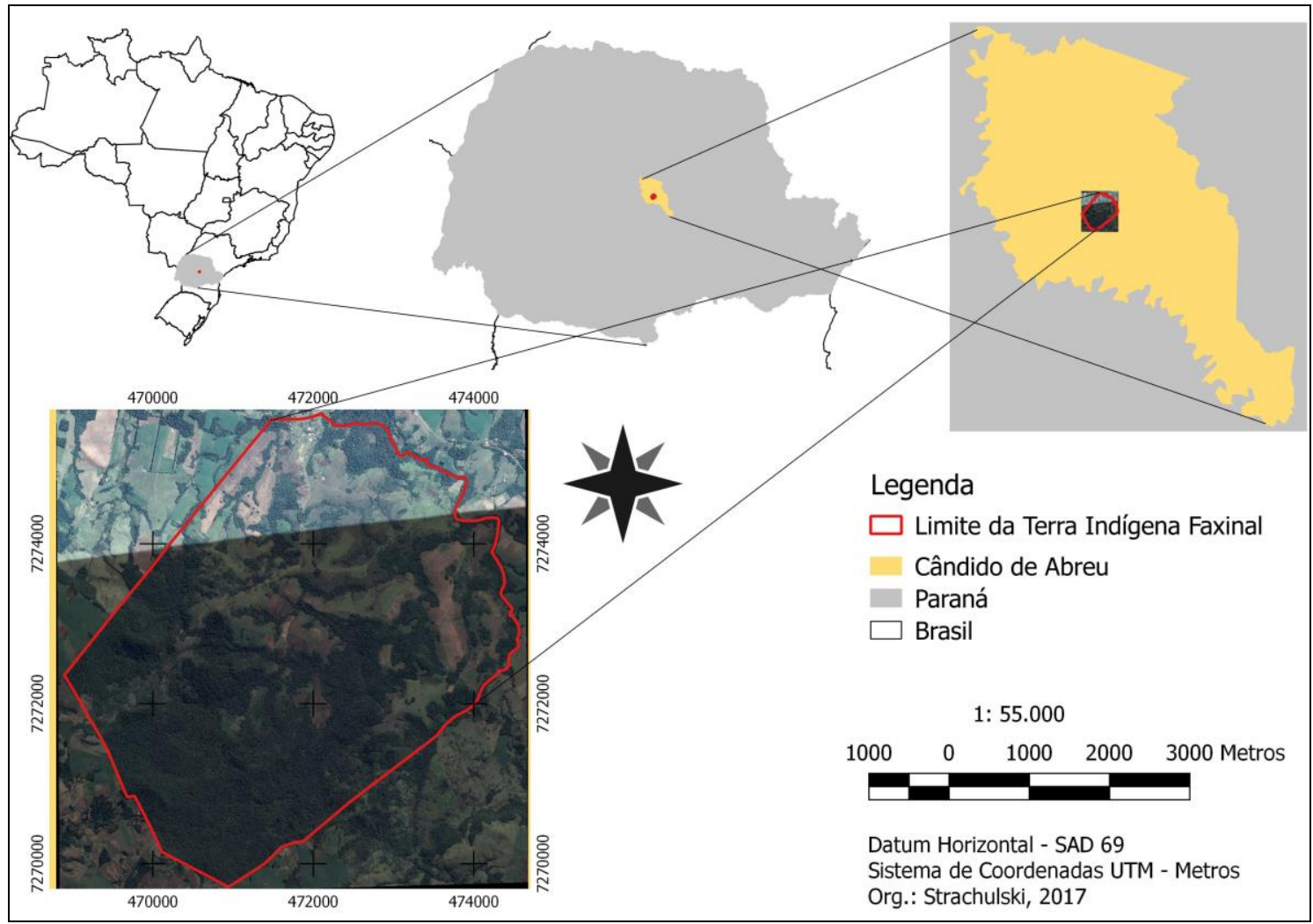

Fonte: STRACHULSKI, 2015.

Os elementos tradicionais e modernos normalmente vistos como em oposição é preciso ter certa ponderação, em razão de que é possível uma compreensão entre esses dois campos, isto é, na capacidade e perspectivas de diálogos indispensáveis à formação de um conjunto de relações capazes de criarem laços de sociabilidade de ampla heterogeneidade. Há relações que ora possibilitam a aproximação entre tradicional e moderno ou que repelem-nos, ou ainda que permitem uma combinação entre ambos.

Sob tais condições, pondera Diegues (2001, p. 87) que a cultura tradicional é definida como um conjunto de exemplos "[...] de comportamento transmitidos socialmente, modelos mentais usados para perceber, relatar e interpretar o mundo, símbolos e signos e significados socialmente compartilhados, além de seus produtos materiais [...]". Estes, estruturam determinados agrupamentos humanos que apreendem códigos, representações e cosmovisões, com valores representativos que são ou podem ser inteligíveis, dentro de uma lógica que são compreendidas ou entendidas como coletividades.

A cultura tradicional, compreendida como aberta ao diálogo com outros modos de vida e seus componentes, absorve elementos externos, a partir de situações de contato (harmônico e/ou conflituoso). Nestes termos, apesenta-se tanto como o resultado de experiências cotidianas, mas não estáticas, e também aberta a interagir com processos e fenômenos de outras culturas, o que comumente, resulta num hibridismo cultural, ocasionado também pelo meio técnico-científicoinformacional no espaço/território.

$\begin{array}{llllll}\text { Caminhos de Geografia } & \text { Uberlândia - MG } & \text { v. 19, n. } 68 & \text { Dez/2018 } & \text { p. 307-325 } & \text { Página } 313\end{array}$


Deste modo, seus saberes e as práticas culturais territorialmente localizadas, a partir do contato entre agrupamentos humanos distintos, para Claval (2007), constitui-se como herança que tem laços no passado e está conectada a um território, onde sua história é narrada, em que repousam seus mortos, registram-se suas batalhas e circunscrevem suas territorialidades, englobam, assim, os elementos internos, próprios de uma cultura, além daqueles que surgiram dos diálogos estabelecidos. Portanto, uma gama de práticas socioculturais territorialmente atrelas, mas não estáticas.

No território da TIF o conjunto de inúmeros valores presentes alude a um hibridismo de atitudes, relações sociais, trabalho, e outras situações, de modo que se refere a "[...] processos socioculturais ou práticas discretas, que existiam de forma separada, e se combinam para gerar novas estruturas, objetos e relações" (CANCLINI, 2008, p. 19).

A partir do contato entre elementos tradicionais e modernos, devido à flexibilidade da tradição, é possível que ocorra uma ressignificação dos elementos modernos e reconstrução ou mesmo uma (re)invenção de tradições que a princípio não eram próprias à cultura tradicional de um povo. Tal condição se caracteriza como hibridismo, ou seja, a ocorrência de fenômenos de apropriação e (re)invenção de tradições, de modo que cria novas matizes culturais com a consolidação e fortalecimento de práticas antes dispersas, e assim atribui-Ihes continuidade (HOBSBAWN e RANGER, 1997), ainda que nelas estejam presentes mudanças e permanências.

A esse respeito sobre tradição inventada, Hobsbawn e Ranger (1997, p. 90) elucidam que trata-se de "[...] um conjunto de práticas, normalmente reguladas por regras tácita e abertamente aceitas; tais práticas, de natureza ritual ou simbólica, visam inculcar certos valores e normas de comportamento através da repetição, o que implica, automaticamente, uma continuidade em relação ao passado".

Ora, o que os autores creditam trata-se de uma não ruptura, mas de uma condição de clivagem cultural ou mesmo de um encaixe-desencaixe, em que a cultura se funde, se amalgama, se expressa e representa como algo que se renova, mas que não abandona em definitivo seus valores mais intrínsecos, nem se desvincula do território em que foram originadas. Na afirmação de Bonnemaison (2002, p. 101-102) isso ocorre "[...] pela existência de uma cultura que se cria um território e é por ele que se fortalece e se exprime a relação simbólica existente entre cultura e espaço".

A partir dessas ancoragens, é possível compreender que na TIF a cultura local - como não deveria deixar de ser - passa por um processo de transformação ou de ressignificação, cujo limite, muitas vezes, é tênue entre as práticas tradicionais e modernas. Fica evidente que em determinados momentos predominam práticas modernas, como a agricultura intensiva e tecnologias digitais, dentre outras, e em outros as tradicionais como as conversas à noite em volta do fogo, o uso da língua materna, agricultura de coivara, dentre outras.

Essa característica de ser tênue, expressa o modo de vida construído com as experiências realizadas desde tempos imemoriais com a necessidade de resistir e sobreviver com a atualidade que se apresenta de maneira intensa e com temporalidades e necessidades que dantes não integravam o cosmo-universo dos Kaingang.

A interação entre moderno e tradicional permite dizer que a relação entre estas situações de viver não deve ser considerada "[...] nem transplante alienado, nem desajuste com a própria realidade: tentativas de organizar o mundo moderno sem abdicar da história" (CANCLINI, 2008, p. 117).

Nesta ótica de não negação é construída a identidade de resistência, ou seja, pela criação e/ou valorização de ideias, apegos, atributos, resiliências por atores que se encontram em condições ou posições desvalorizadas, estigmatizada pela lógica de dominação ou subalternos (CASTELLS, 2002; SPIVAK, 2010) a enfrentar desafios, como luta pela sobrevivência e serem considerados como subversivos. A realidade vivida é que impulsiona tais encorajamentos, ainda que tenham parcelas consideráveis da sociedade e do Estado a atuar de modo contrário e opressor quanto às demandas originadas do povo.

A identidade de resistência, como pertence às práticas (i)materiais tradicionais que caracterizam a cultura local, considerada como um dos aspectos de representação simbólica da cultura Kaingang: reuniões entre as lideranças, os mutirões, a língua materna, que em conjunto à organização social baseada na divisão em metades exogâmicas Kamẽ e Kanhru, por meio dos casamentos entre essas pessoas que compõe esse povo - ainda que cada vez mais influenciada pelas religiões ocidentais constitui-se como um dos elementos que se caracteriza como pertinência e permanência dos valores Kaingang.

$\begin{array}{llllll}\text { Caminhos de Geografia } & \text { Uberlândia - MG } & \text { v. 19, n. } 68 & \text { Dez/2018 } & \text { p. 307-325 } & \text { Página } 314\end{array}$


Em tal direção, avalia Marques (1994) que "[...] o modo de vida tradicional significa um conjunto de práticas cotidianas desenvolvidas por um determinado grupo social decorrente da sua história, posição social ocupada, como forma de assegurar a sua reprodução social [...]", o que localmente é representado pela língua materna: o Kaingang e pelos valores culturais, sociais e espirituais que construíram desde tempos imemoriais, os quais mantêm aqueles que consideram mais representativos em seu modo de vida.

Outros elementos tradicionais, mas que são ressignificados atualmente, são a confecção do artesanato; os momentos de tomar o mate, que é ou não compartilhado entre os membros do povo (Figura 2); os saberes tradicionais, a caça e a pesca, em especial o pari (Figura 3), embora seja pouco praticada, em parte, devido às perdas territoriais; além das tatuagens que as crianças (tatuagem temporária) e os adultos (tatuagem permanente) possuem no rosto.

Figura 2: Elementos tradicionais da cultura Kaingang: a partilha do chimarrão (kógwuin) e a produção do artesanato

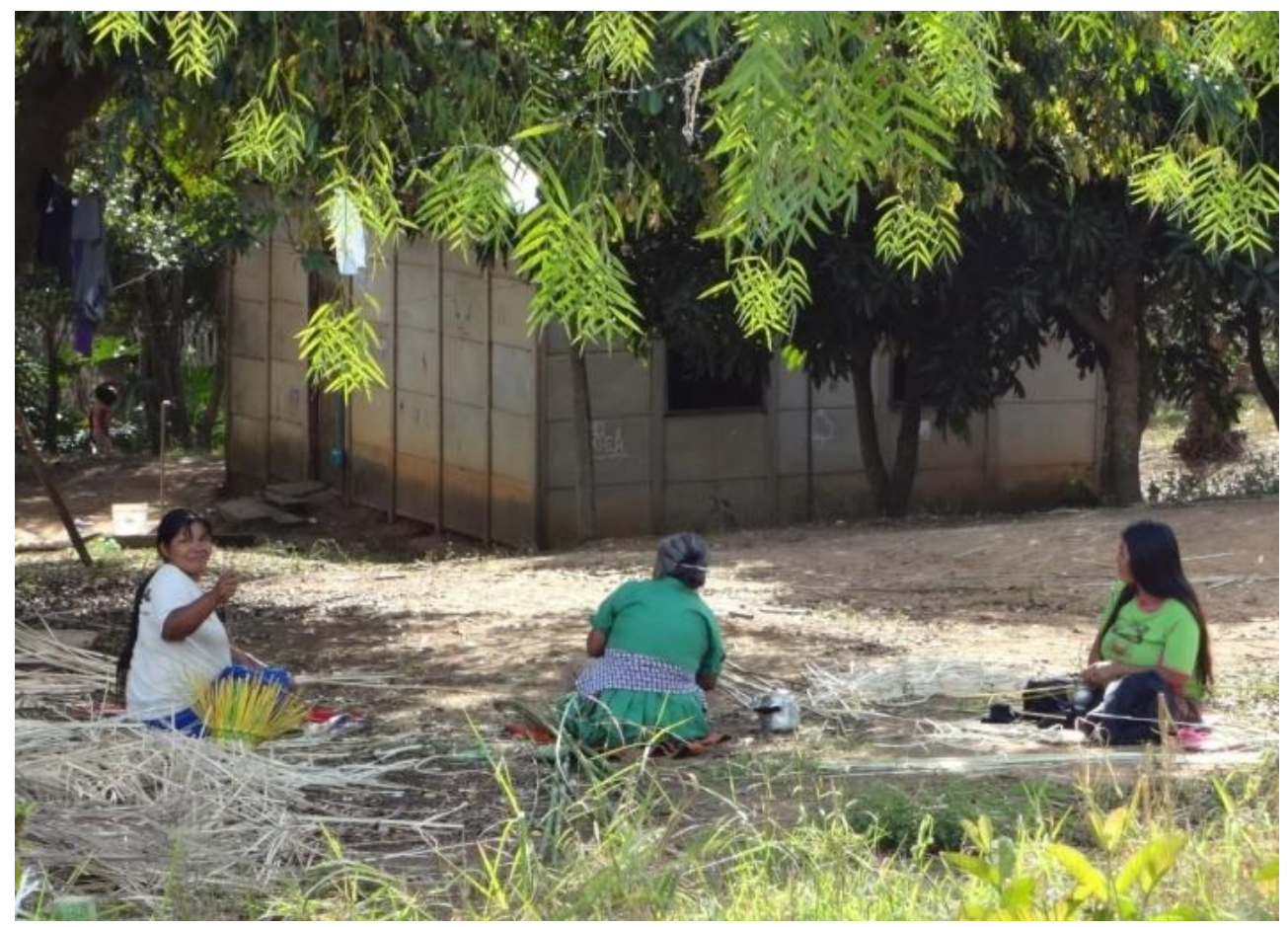

Fonte: STRACHULSKI, 2015.

O pari é uma prática tradicional de pesca, que consiste em trançar taquara (Chusquea $s p$.), para tanto, faz-se uma esteira - coloca-se sobre uma armação feita de galhos de árvores que se eleva para cima do nível da água - ela é introduzida dentro de um funil constituído de uma parede de pedras, na qual direciona-se a água e os peixes, sua construção é realizada em uma corredeira.

$\mathrm{O}$ artesanato e o chimarrão constituem-se em práticas tradicionais que foram ressignificadas. $\mathrm{O}$ artesanato no passado possuía um uso prático, como a confecção dos arcos e flechas para a caça e pesca, bem como a cestaria para transporte de alimentos (milho, mandioca, etc.). Atualmente sua produção tem finalidade econômica, isto é, utilizada como um meio de auferir renda para o sustento das famílias.

Tal prática, ainda possibilita que os Kaingang percorram longas distâncias, com o deslocamento pelas cidades vizinhas à sua aldeia - com acampamentos próximos às rodoviárias, em abrigos temporários cobertos por lonas - o que tem o sentido de ressignificar outra prática que era a de percorrer longas distâncias por comida e acampar na mata, o que atualmente se torna impossível devido à redução de seu território. 
Figura 3: Elemento tradicional da cultura Kaingang: o pari

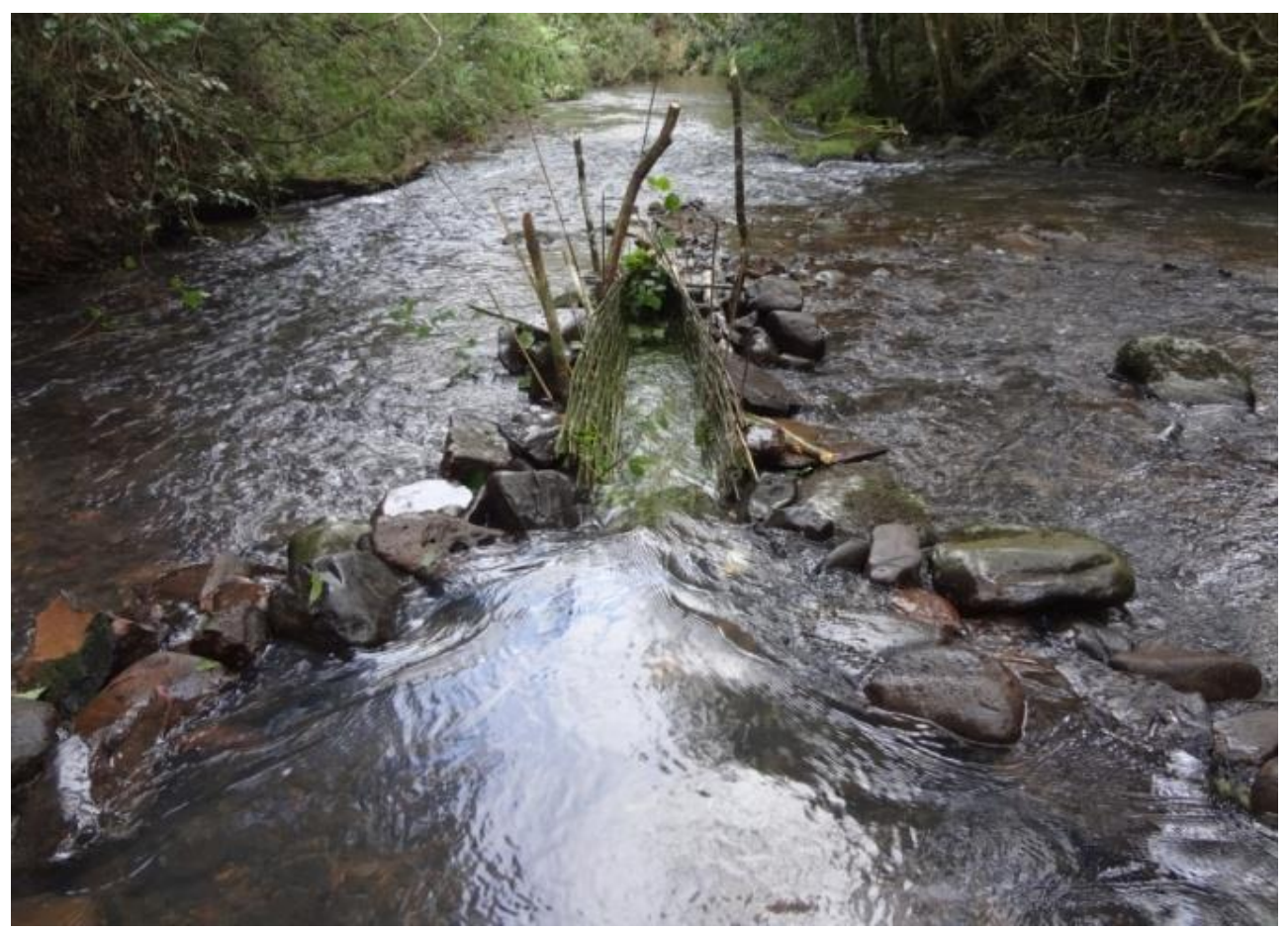

Fonte: STRACHULSKI, 2015.

Tal prática, ainda possibilita que os Kaingang percorram longas distâncias, com o deslocamento pelas cidades vizinhas à sua aldeia - com acampamentos próximos às rodoviárias, em abrigos temporários cobertos por lonas - o que tem o sentido de ressignificar outra prática que era a de percorrer longas distâncias por comida e acampar na mata, o que atualmente se torna impossível devido à redução de seu território.

Essa territorialidade dos Kaingang da TIF é caracterizada como uma estratégia, que se coloca "[...] dentro do contexto de motivações humanas e objetivas" (SACK, 1986, p. 25). Essa estratégia é colocada em prática com várias finalidades, representações e significados, de acordo as pretensões dos sujeitos, do momento sociocultural e da própria situação em que vive. Nesse caso, com o deslocamento para além de seu território tradicional, oportuniza a comercialização do artesanato.

Quanto à prática do chimarrão, no passado mascava-se as folhas da erva ou tomava-se mate de água fria, era utilizada pelos indígenas para tratar de ressacas causadas pela ingestão de bebidas fermentadas como o kiki (bebida composta por mel e água), ou seja, como fim medicinal. Por outro lado, também era utilizado para questões espirituais como ritos de adivinhação (HAVERROTH, 1997) e era conduzida por seus xamãs (cuiãs).

Atualmente o chimarrão é um meio de reunir e acolher o outro, de possibilitar a união entre pessoas. Exemplo de que o mate é convidativo está expresso na Figura 2, pois ali se toma chimarrão e confecciona artesanato, no que se denomina de puxirãozinho ou pequena reunião de pessoas para se realizar algum tipo de trabalho.

Outro elemento que avaliado como ressignificado é a utilização de tatuagens no rosto, que relembra a tradição da pintura corporal Kaingang, que, no passado, de acordo com Veiga (2006) diferenciava os Kamẽ de pintura facial com motivos compridos (râ téi) dos Kanhru com motivos redondos (râ rôr).

A maioria das crianças possuem tatuagens de chicletes em algumas partes do corpo (como a testa, o pescoço e a bochecha), além de os adultos possuírem tatuagens na testa, alguns desses grafismos se assemelham a riscos compridos e outras a bolinhas, o que está diretamente relacionado às duas metades clãnicas. É possível que talvez nem as crianças nem alguns adultos saibam sobre isso, mas está intrínseco ao ser Kaingang.

$\begin{array}{llllll}\text { Caminhos de Geografia } & \text { Uberlândia - MG } & \text { v. 19, n. } 68 & \text { Dez/2018 } & \text { p. 307-325 } & \text { Página } 316\end{array}$


Mas nem só de práticas tradicionais vive o povo Kaingang, em razão da presença das tecnologias modernas como o telefone móvel, os microcomputadores, e a agricultura moderna. Destarte, em quase todos os locais se percebe a modernidade, ou seja, há hibridização, pois esta não repele os elementos tradicionais, mas resulta em sua inserção, de modo que possibilita a imbricação de características que aproximam temporalidades, objetos e lugares (CANCLINI, 2008).

Atualmente na TIF se percebe que na cultura local ocorre um processo de transformação, com isso há um conflito latente entre práticas tradicionais e modernas. Neste caso, a lógica moderna do capital, normalmente, se sobrepõe a outros modos de vida, ou seja, tem como características o domínio e controle sobre esses. Contudo, ainda assim, tradicional e moderno coexistem dento de uma mesma sociedade.

Muitos elementos da modernidade, expressivamente difundidos na sociedade urbano-industrial chegaram a TIF, com isso estimulam a disseminação do modo de vida moderno, cujas principais características são o apego e consumo de bens materiais, o individualismo e a valorização da cultura de massa. Os telefones móveis, o rádio, a TV e os microcomputadores incentivam essa hibridização nas práticas sociais, o que é constatada nas festas locais, as quais incorporam estilos musicais urbanos, como exemplo o funk, gauchesco, forró, sertanejo, conjuntamente com outras características tradicionais locais.

A presença de pessoas com um modo de vida carregado de elementos da modernidade, normalmente de hábito de vida urbano, nas festas locais, bem como no cotidiano, como os professores e funcionários não indígenas das escolas locais, vendedores e outros, também contribuem para uma incorporação de novos valores aos já estabelecidos ao longo de décadas a outras práticas culturais não indígenas no território original e/ou ancestral.

Nestas circunstâncias, o território local é concebido como uma "[...] imbricação de múltiplas relações de poder, do poder mais material das relações econômico-políticas ao poder mais simbólico das relações de ordem mais estritamente cultural" (HAESBAERT, 2004, p. 74). Quanto ao território local, é perceptível a ordem cultural, pois, as práticas socioculturais não indígenas se instituem, impõem e fazem parte da estrutura territorial na atualidade; nesta perspectiva o território se torna o resultado da relação de um ou mais agrupamentos humanos com o espaço. Há uma inter-relação de territorialidades e práticas socioculturais distintas que se traduzem em (re)arranjos territoriais híbridos.

Deste modo, a cultura local procura se adaptar ao contexto sociocultural em que está inserida, assim se abre, modifica elementos tradicionais e assimila códigos da cultura moderna, os quais acarreta situações de apreensão e stress no cotidiano dos moradores locais.

Não obstante, o processo tensionado fruto do embate entre moderno e tradicional gera um hibridismo que na visão de Canclini (2008) não é um processo ameno, pois não é uma simples adaptação, em virtude de produzir alterações e assimilações, o que se consubstancia como o choque entre fenômenos e processos concebidos e praticados em escalas diferenciadas por culturas e modos de vida distintos.

Os Kaingang ao ficarem doentes utilizam plantas da floresta para remédio, mas com a presença de um posto de saúde na aldeia, tal prática sofre alteração, com isso os medicamentos industrializados passam a destacar relevância em detrimento da medicina ancestral. A transmissão de conhecimentos sobre plantas medicinais e ritualísticas, está cada problemática, pois os conhecedores dessas práticas encontram-se em idade elevada e em número reduzido, logo os mais novos recorrem aos medicamentos do posto de saúde devido à facilidade de obtenção, ainda que tais remédios industrializados possam ter efeitos colaterais intensos e em inúmeras vezes até também prejudiciais à saúde.

No tocante as práticas de trabalho, em especial a agrícola, detectamos alguns elementos que entendemos como híbridos, tais como a presença de sementes crioulas, a semeadeira manual, conhecida como perna de grilo (Figura 4) e roça no toco de um lado e, por outro lado, a existência de semeadeira motomecanizada, tratores, uso de agrotóxicos, fertilizantes e revolvimento do solo (Figura 5).

Essas constatações têm por efeito a relação direta com o aumento da produtividade, a qual é fomentada pela mecanização, bem como a inserção dos Kaingang - ressalvada a segurança alimentar - na lógica determinada pelas necessidades promovidas pelo mercado consumidor nacional e internacional, ou seja, pelos interesses promovidos pela globalização econômica. 
Figura 4: Elemento da agricultura tradicional: semeadeira manual

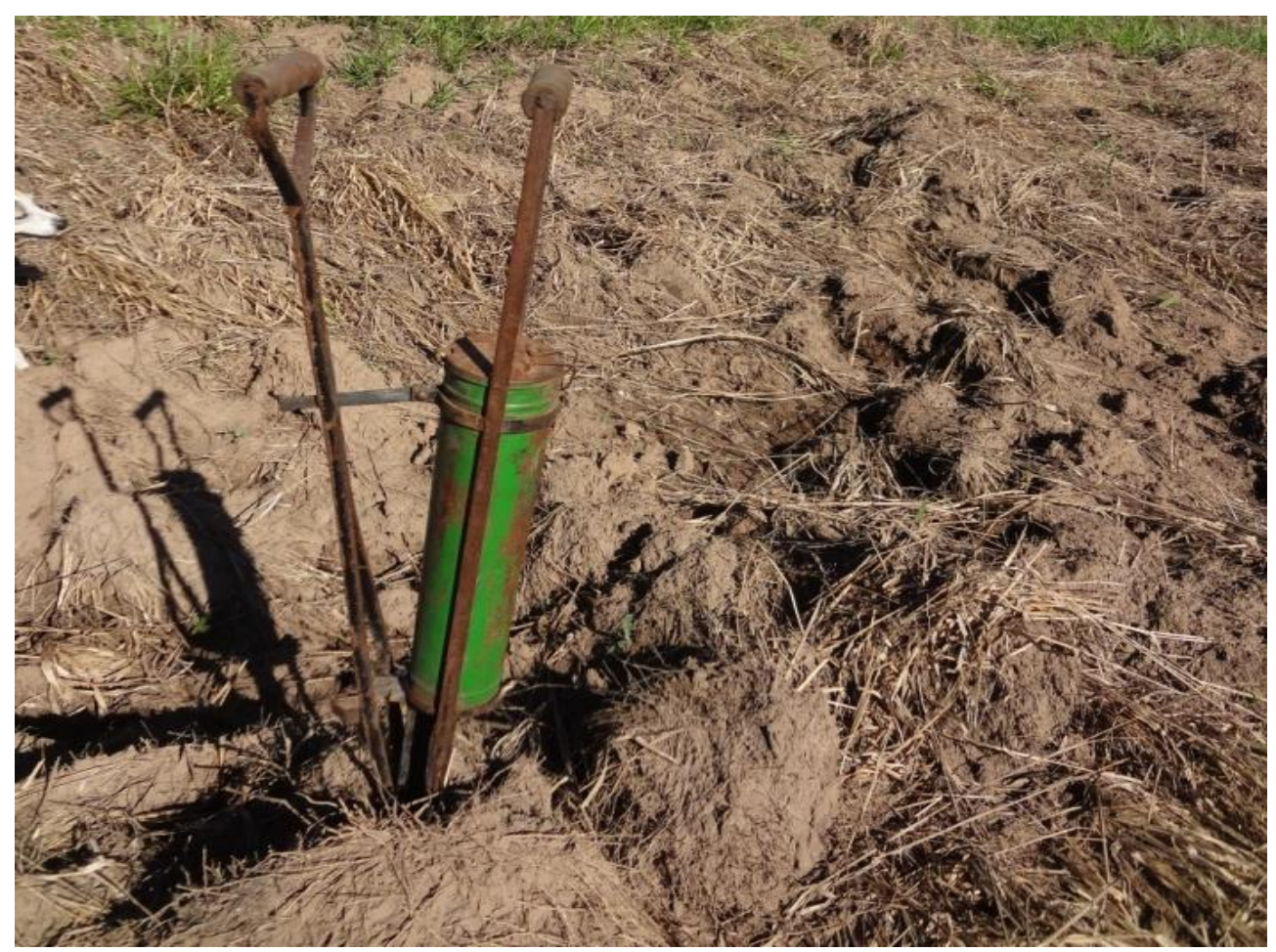

Fonte: STRACHULSKI, 2015.

Figura 5: Elemento da agricultura moderna: semeadeira motomecanizada

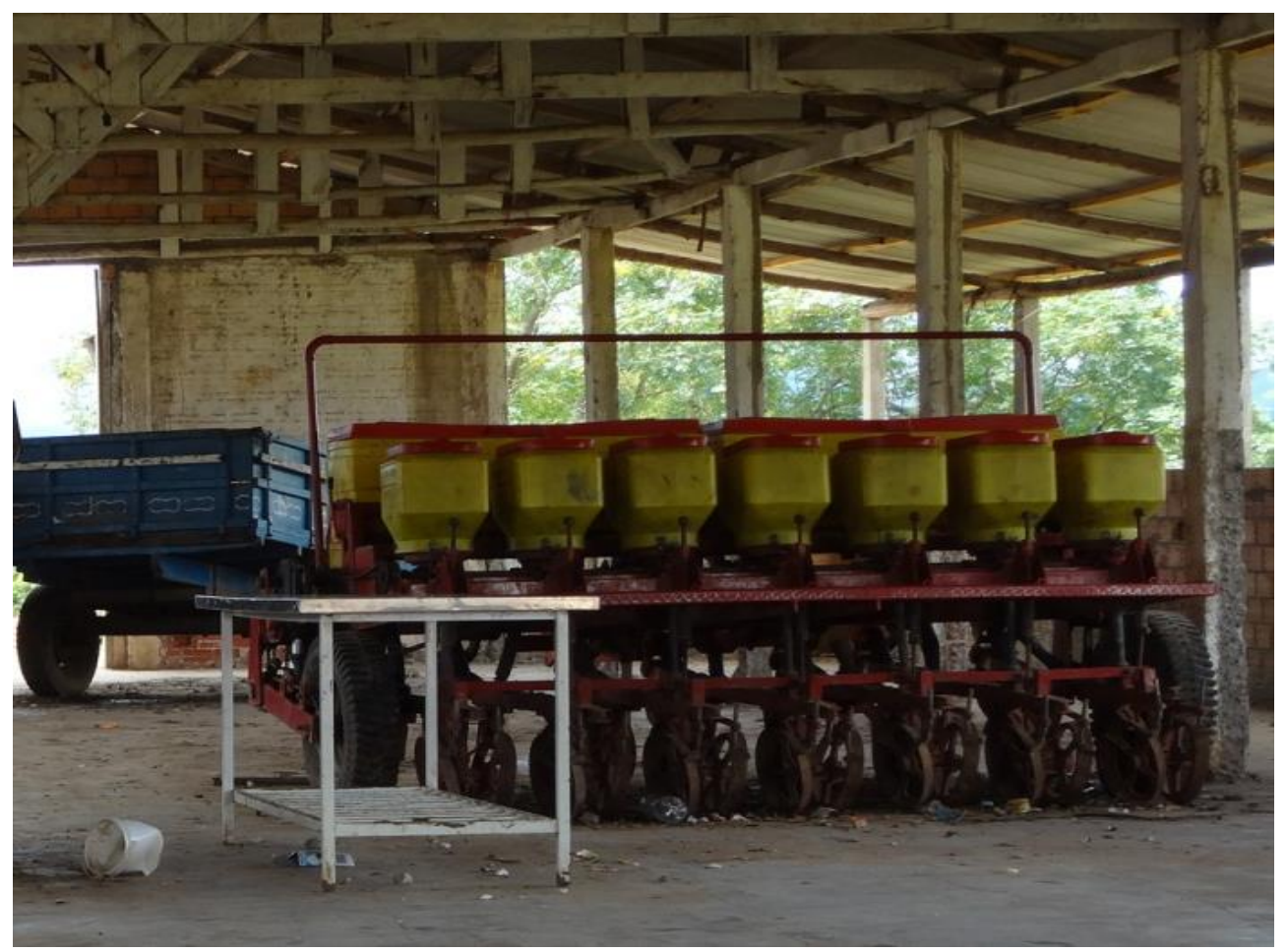

Fonte: STRACHULSKI, 2015. 
Tal situação, embora não seja objeto específico do presente trabalho, tem rebatimento direto na vida desse povo originário, uma vez que a modernização na agricultura representa a perda da biodiversidade, assim como a utilização de defensivos e produtos que apresentam elevados níveis de contaminação/poluição e que resultam na propagação de enfermidades e diminuição da qualidade de vida da população.

Outras práticas assíduas ao trabalho agrícola são a "troca de dias" de serviço na lavoura e o plantio "de as meia" (a produção é dividida entre o dono da área e quem produz). Também utilizam cavalo para transportar milho na roça, devido à agricultura ser cultivada sob coivara. Em função das dificuldades do terreno, até mesmo o próprio agricultor transporta parte da produção nas costas para um local de mais fácil acesso a tratores e demais veículos. Nestas terras também são reproduzidos ao longo do tempo cultivos tradicionais como o milho (Zea mays), o feijão (Phaseolus vulgaris), a abóbora (Cucurbita spp), a mandioca (Manihot esculenta), dentre outros, mediante técnicas tradicionais.

De outra maneira, se intensifica a presença de elementos da modernização da agricultura, como seu arcabouço instrumental (maquinário agrícola e veículos automotores) e químico-genético (adubos, agrotóxicos e sementes geneticamente modificadas), voltados seus esforços para a produção de soja em extensas áreas. Assim, ocorre uma diminuição de plantios diversificados ou de policultivos, que passam a ocupar papel secundário no sistema agrário local.

A diminuição de plantios da roça no toco (feita de modo tradicional com encoivaramento e queima da biomassa, é realizada por meio do trabalho familiar ou comunitário e é destinada à produção de alimentos para a subsistência, de modo que a fauna e a flora sejam menos agredidas do que na agricultura mecanizada), bem como de busca por plantas medicinais, resulta no apontamento que a territorialidade é construída socialmente, pois, "Ela precisa de um ato do desejo e envolve múltiplos níveis de razão e significados" (SACK, 1986, p. 32). Deixar de lado ou diminuir a intensidade de relações com determinados territórios infere que os atores sociais locais têm estabelecido diferentes níveis de acesso a esses, com isso dá-se prioridade a alguns em detrimento de outros, significativamente em decorrência dos ditames da agricultura moderna ocasionada pela cultura dos não indígenas.

Por outro lado, se constata "[...] o fato de que os homens estejam inscritos numa continuidade e sejam sempre herdeiros não os priva de criatividade" (CLAVAL, 2007, p. 86), o que torna evidente que as práticas socioculturais, de trabalho e outras não precisam e talvez não seja possível sua reprodução por completo ao longo do tempo. Isso demonstra uma capacidade de improviso da cultura local, que muitas vezes se deixa influenciar pelo modo de vida moderno, mas que resiste com o passar dos anos.

Destarte, ocorra a hibridização, a qual explicita a existência de processos e/ou fenômenos que não se mesclam, visto que "[...] uma teoria não ingênua da hibridação é inseparável de uma consciência crítica de seus limites, do que não se deixa ou não quer ou não pode ser hibridado" (CANCLINI, 2008, p. 27). Nestes casos, citamos que as práticas tradicionais consolidadas no passado (língua e divisão clãnica) e aquelas inventadas, consolidadas no presente, como os bailes, o futebol e as rezas.

Em conformidade com Hobsbawm e Ranger (1997, p. 19) há uma perceptível diferença entre práticas antigas e inventadas. "As primeiras eram práticas sociais específicas e altamente coercivas, enquanto as últimas tendiam a ser bastante gerais e vagas [...]".

Os mesmos autores ainda apontam e compreendem que as tradições inventadas mais recentes não precisam se inserir num passado longínquo, perdido no tempo. Assim, ao fazerem referência a um passado histórico se caracterizam por apresentar uma continuidade, um elo, artificial, as quais "[...] são reações a situações novas que ou assumem a forma de referência a situações anteriores, ou estabelecem seu próprio passado através da repetição quase que obrigatória" (HOBSBAWM e RANGER, 1997, p. 10).

O que diferencia um processo de hibridismo cultural de outro que resulte na invenção de cultura está na temporalidade, mas não numa situação concreta de existência de um determinado fenômeno ou processo. Pois, o hibrido não tem um passado, trata-se de uma combinação de elementos que não estavam aliados e que passaram a estabelecer relações devido a vários fatos: necessidade, imposição, resistência, dentre outros. 
Por sua vez, a (re)invenção de tradição possui um passado inventado em comum muito rico e capaz de modelar o presente e possibilitar uma coesão sociocultural entre os membros de um povo. Portanto, a invenção de tradição ocorre na seguinte condição:

\begin{abstract}
Quando uma transformação rápida da sociedade debilita ou destrói os padrões sociais para os quais as "velhas tradições" foram feitas, produzindo novos padrões com os quais essas tradições são incompatíveis; quando as velhas tradições, juntamente com seus promotores e divulgadores institucionais, dão mostras de haver perdido grande parte da capacidade de adaptação e da flexibilidade; ou quando são eliminadas de outras formas. Em suma, inventam-se tradições quando ocorrem transformações suficientemente amplas e rápidas tanto do lado da demanda quanto do lado da oferta (HOBSBAWM e RANGER, 1997, p. 12).
\end{abstract}

Assim, os bailes com música gaúcha (Figura 6), as festas de santos (Nossa Senhora, Santo Antônio, São João, dentre outras) (Figura 7), a prática do futebol, os velórios com rezas cristãs, as cadeias, as missas e cultos são tradições inventadas.

Figura 6: As tradições inventadas: os bailes com músicas gaúchas

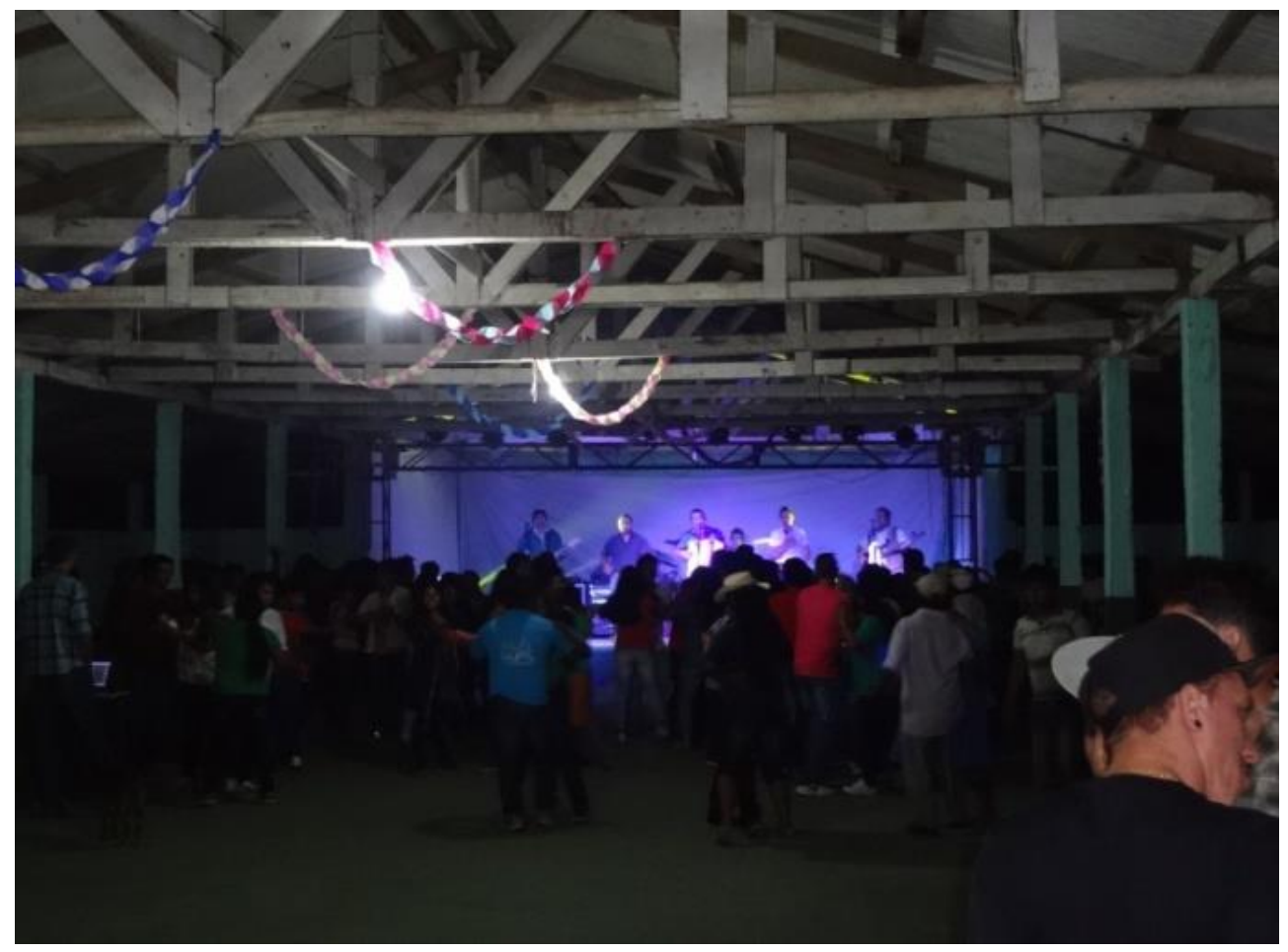

Fonte: STRACHULSKI, 2015.

Neste caso, se constata a presença de marcadores territoriais (da própria cultura) e os demarcadores territoriais (introdução/adaptação de valores culturais de outros povos), com isso, ocorre o processo de hibridização, ou seja, caracteriza-se como uma terceira via. Como tal entendemos que já não se trata mais de uma cultura originária, tampouco de uma somente externa, e sim, uma junção transformada em uma nova, mas que guarda fragmentadas das anteriores.

Os bailes com música gaúcha são muito frequentes na TIF, e são realizados em datas comemorativas, como dia do índio (também tradição inventada), festas juninas ou atendem as demandas locais.

Em certas ocasiões festivas ocorrem a participação de bandas, as quais são contratadas, mediante as possibilidades econômicas de quem queira e pode custear essas despesas. O baile em si, conta

$\begin{array}{llllll}\text { Caminhos de Geografia } & \text { Uberlândia - MG } & \text { v. 19, n. } 68 & \text { Dez/2018 } & \text { p. 307-325 } & \text { Página } 320\end{array}$


com a presença ou não de não-indígenas, começa tarde da noite e vai até o amanhecer do dia, nele ocorre ou não a venda de bebidas fermentadas como a cerveja.

As festas de santos são consideradas como tradições inventadas, contam com a reza do terço e queima de fogos, todos atributos da cultura não-indígena. Contudo, diferente da língua, prática agrícola e artesanato que são valores transmitidos de geração a geração, as tradições inventadas estão sujeitas a serem (re)inventadas. Portanto, diferente dos valores tradicionais que são rígidos, ou seja, que não mudam a todo instante, percebe-se que existe certa compatibilidade e semelhança ao seu precedente (HOBSBAWM e RANGER, 1997).

Figura 7: As tradições inventadas: as festas de santos

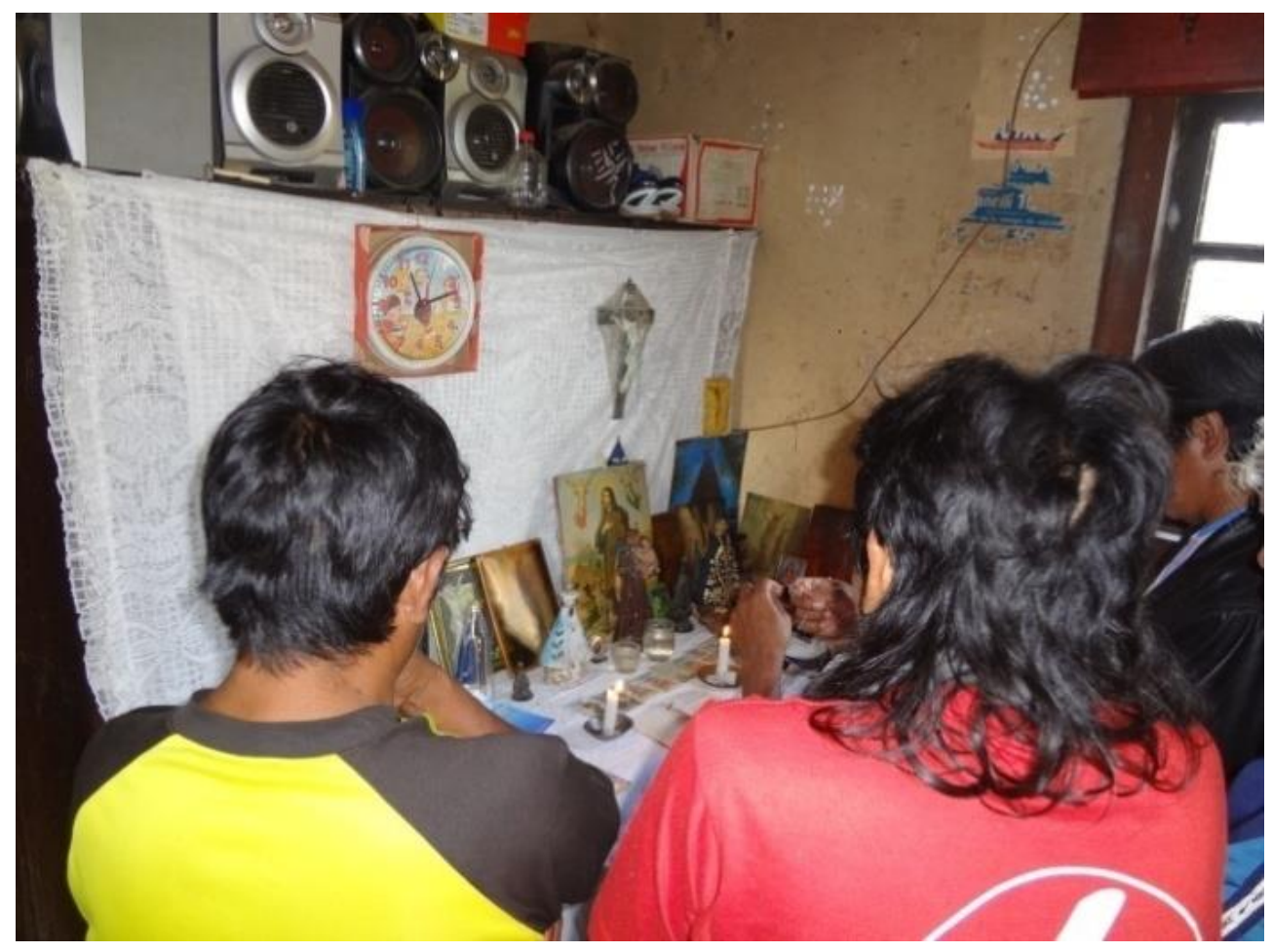

Fonte: STRACHULSKI, 2015.

As continuidades históricas que esses eventos representam revelam um elemento incorporado ou inventado, pois "[...] a inovação não se torna menos nova por ser capaz de revestir-se facilmente de um caráter de antiguidade" (HOBSBAWM e RANGER, 1997, p. 13). Por tal motivação foi utilizado o termo "invenção", em decorrência de que remete ao passado, mas que esses postulados se colocam e atrelam ao presente atual por meio de fenômenos e processos que oferecem sentido à motivação de vida e do compósito das relações sociais, políticas e culturais.

Jogos com times de futebol são frequentemente realizados aos sábados e domingos promovidos pelas lideranças locais, mas também ocorrem no meio da semana, para tanto, depende da disponibilidade dos jogadores e da realização de determinados eventos, como campeonatos de futebol locais ou municipais. É uma atividade que também contempla crianças que aprendem a jogar futebol desde muito jovens. Independente dos dias, continuamente conta com um bom público que acompanha o jogo, desde os novos até os mais velhos. Por isso é considerado um atributo que compõe o corolário cultural dos Kaingang.

No caso das cadeias (Figura 8), essas são um legado do antigo Serviço de Proteção aos Índios - SPI, ligadas a um mecanismo de controle social baseado em pressupostos coercitivos e até mesmo violentos de punição, como amarrar no tronco, para tanto, os Kaingang contam com uma polícia indígena (ALMEIDA e NÖTZOLD, 2013).

Apesar da extinção do SPI, e a FUNAI não incentivar tal prática, os Kaingang adotaram esse sistema ao longo do tempo. Atualmente a polícia indígena na TIF prende e leva para a cadeia aqueles

\begin{tabular}{llllll}
\hline Caminhos de Geografia & Uberlândia - MG & v. 19, n. 68 & Dez/2018 & p. 307-325 & Página 321
\end{tabular}


indígenas que cometeram algum ato infracional, conforme códigos locais, logo, atos como consumo de bebida alcoólica, discussão com seu cônjuge, desacato às lideranças, mulher que não sabe de quem engravidou, roubos, dentre outras situações, são passíveis dessas intervenções coercitivas.

Neste sentido, compreendemos o que afirmam Hobsbawm e Ranger (1997) que as tradições são sempre invenções, que surgiram em algum momento no passado e que no futuro sofrerão alguma alteração - por ser dinâmica, ou seja, se a cultura e as relações sociopolíticas sofrem transformações, os valores construídos por determinado povo também, em virtude da própria dinâmica que se coloca no meio desse povo.

Figura 8: As tradições inventadas: as cadeias

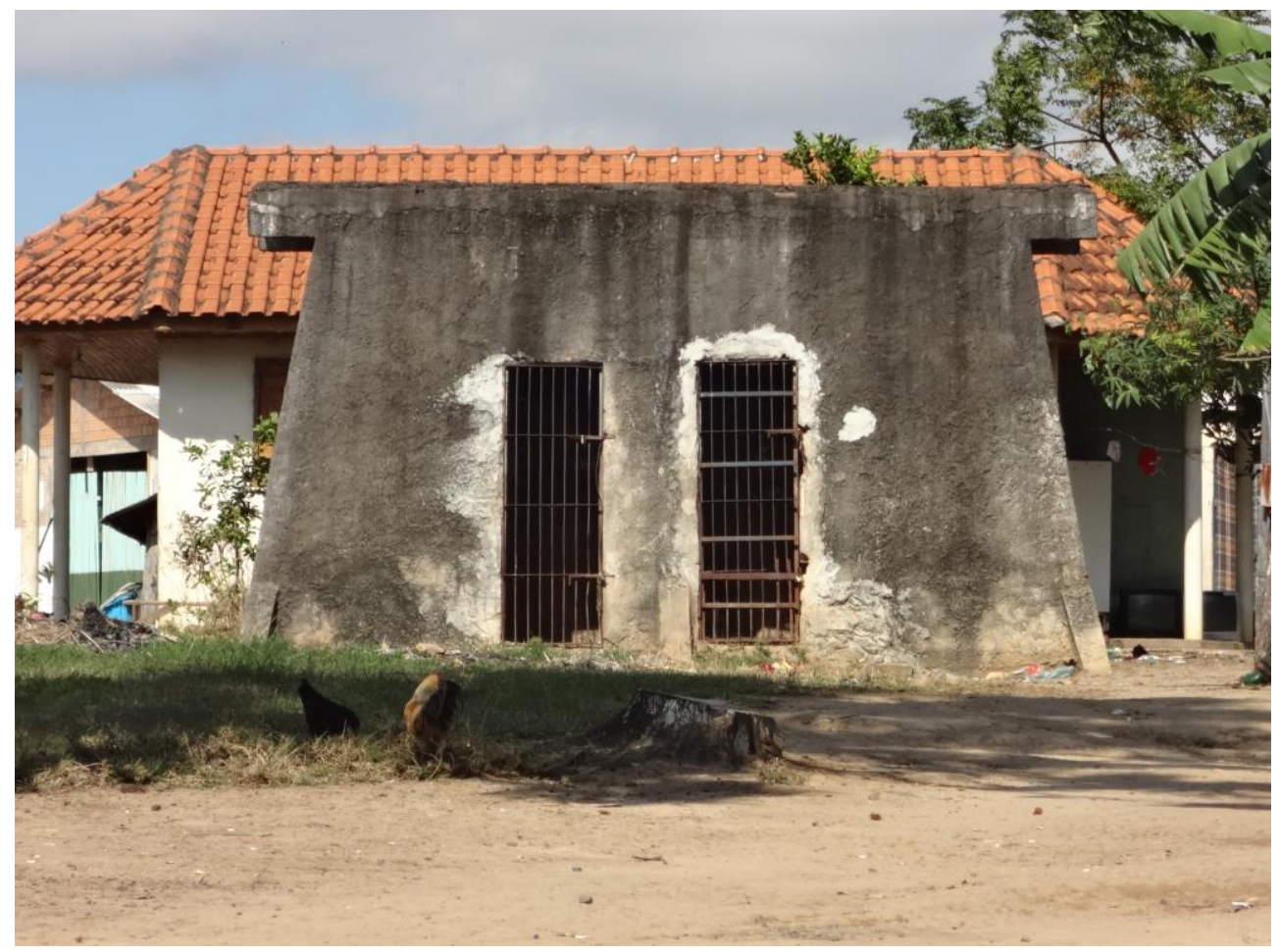

Fonte: STRACHULSKI, 2015.

A partir da visão de que um território comporta uma dimensão cultual e outra política. No tocante as cadeias se evidencia a última, pois além de concreta, possui caráter político-disciplinar, que influencia na ocupação e ordenamento do espaço, desse modo, com a objetivação para dominar e disciplinar os sujeitos (HAESBAERT, 2004). A presença das cadeias, assim, atua como inibidora de ações consideradas negativas para as condutas culturais locais a partir de uma estrutura político-cultural da cultura envolvente.

As mudanças são constantes em relação às tradições e aos valores culturais, sociais e políticos, contudo, há algo estabilizador: a persistência/resiliência com a permanência desses valores, das práticas/vivências ou de algum fenômeno que tem a capacidade de continuidade, o que caracterizase como resistir as tensões que ocorrem ao longo dos tempos.

A tradição é reavivada, restaurada e (re)significada graças as referências que à ela possam sobrepor temporalmente, por meios materiais e/ou imateriais e que reportam ao passado, vivido ou imaginado - construído no passado e transposto ao presente.

\section{CONSIDERAÇÕES FINAIS}

O presente ensaio almejou demonstrar a relação entre as práticas socioculturais territoriais atuais dos Kaingang da Terra Indígena Faxinal - TIF, de modo a caracterizar algumas variáveis que se realizam como um embate entre o moderno e o tradicional, além da ressignificação e (re)invenção de tradições

\begin{tabular}{llllll}
\hline Caminhos de Geografia & Uberlândia - MG & v. 19, n. 68 & Dez/2018 & p. 307-325 & Página 322
\end{tabular}


e de valores culturais, sociais, políticos e espirituais, como uma tentativa de ponderar aquilo que foi construído pelo modo de vida desse povo e que ao longo do contato com o não-indígena passaram por mudanças, enquanto outros desses valores ainda resistem.

Ressaltamos que novos e complementares estudos geográficos e de outras áreas do conhecimento sobre a temática necessitam ser realizados e aprofundados empírica e teoricamente, em decorrência do período breve de vivência nosso com os Kaingang, vez que um ensaio, entendemos como não suficiente para compreender a complexidade territorial e humana existente. Advertimos que o texto não se refere a um julgamento, mas de uma constatação em que os Kaingang historicamente após o contato com a sociedade envolvente - a não-indígena - passaram e passam por um violento processo de negação, com exclusão e invisibilidade social.

Ao longo do tempo e ao largo do espaço os Kaingang da TIF se inseriram em um processo de interação intensa com a sociedade abrangente, buscam-se adaptar ao momento socioeconômico e cultural do qual integram, por meio de contexto de mudanças e permanências, no qual ocorre rupturas, hibridizações, ressignificações e de (re)invenção de suas tradições e de seus valores culturais, sociais, políticos e espirituais.

Neste sentido, consideramos o que afirma Claval (2007) ao descrever a condição humana, a qual está inscrita numa continuidade, mas apesar disso não é desprovida de criatividade, assim é notório que há uma necessidade em preencher aquilo que não se apresenta completo pelas circunstâncias socioculturais atuais. Esta condição contribui para a promoção do hibridismo cultural com suas ressignificações e suas (re)invenções de tradições e valores, que de certo modo reorganizam a cultura local ao mesmo tempo, ou seja, constitui-se um processo incompleto e inacabado.

Em determinadas circunstâncias foi possível perceber que prevalecem elementos criados, em outras são os modernos e em outras mais os tradicionais, ou seja, trata-se de disputas de narrativas que ocorrem no território, onde em primeiro momento tem-se a percepção que discurso de fora sobrepõe ao originalmente concebido pelos indígenas. É necessário um olhar com profundidade, vez que o exercício memorial é algo que se efetiva presencialmente entre esses povos.

Destarte, os Kaingang da TIF vivem em duas dimensões: o seu com valores tradicionais/imemoriais, culturais, identitários, espiritualidades e sociabilidades, e por outro lado com o moderno representado pelo meio técnico-científico-informacional que avança sobre seus territórios e territorialidades. Assim, buscam se adaptar a este choque entre perspectivas culturais distintas e reforçam seus anseios e suas convicções e cosmovisões, mediante o estabelecimento de um protagonismo/proativismo como povo, como condição de deixarem a subalternidade, aprenderem e exercitarem os códigos da sociedade externa. Para tanto, a educação formal é um dos caminhos presente nesses códigos.

Por fim, destaca-se que ao longo da história recente de transformações culturais aliado a perdas territoriais a que foram submetidos, constata-se que "[...] muitas tradições perderam-se no tempo, outras se simplificaram, novas foram criadas, mas a lógica social e os princípios estruturantes do pensamento Kaingang continuam ativos" (TOMMASINO, 2002, p. 97). Deste modo, consubstanciam seus marcadores territoriais como permanências e os demarcadores territoriais como mudanças ou processos de apreensão/incorporação de novos valores provenientes da sociedade envolvente.

\section{REFERÊNCIAS}

ALMEIDA, C. S.; NOTZOLD, A. L. V. Como civilizar o índio?! O Serviço de Proteção aos Índios (SPI) e a integração dos Kaingang no sul do Brasil: o Posto Indígena Xapecó entre práticas de desenvolvimento e controle social. In: XXVII SIMPÓSIO NACIONAL DE HISTÓRIA, 27., 2013, Natal. Anais eletrônicos... Natal: ANPUH, 2013. Disponível em: <http://www.snh2013.anpuh.org/resources/anais/27/1371150990_ARQUIVO_TEXTOCOMPLETOCari naSantosdeAlmeidaDOC.pdf >. Acesso em: 25 de outubro de 2017.

ALMEIDA SILVA, A. Impactos socioculturais em populações indígenas de Rondônia: Estudo da Nação Jupaú. Dissertação (Mestrado em Geografia) - Porto Velho: UNIR, 2008.

Territorialidades e identidade dos coletivos Kawahib da Terra Indígena Uru-Eu-WauWau em Rondônia: "Orevaki Are" (reencontro) dos "marcadores territoriais". Tese (Doutorado em Geografia) - Curitiba: UFPR, 2010. 
Territorialidades, identidades e marcadores territoriais Kawahib da Terra Indígena Uru-Eu-Wau-Wau em Rondônia. Jundiaí: Paco Editorial, 2015a.

Entre a floresta e o concreto: os impactos socioculturais no povo indígena Jupaú em Rondônia. Jundiaí: Paco Editorial, 2015b.

BONNEMAISON, J. Voyage autour du territoire. L'Espace Geógraphique, Paris, n. 4, p. 249-262, 1981. Disponível em: <https://www.persee.fr/doc/spgeo_0046-2497_1981_num_10_4_3673>. Acesso em: 21 de novembro de 2018.

BONNEMAISON, J. Viagem em torno do território. In: CORRÊA, R. L.; ROSENDAHL, Z. (Orgs.). Geografia cultural: um século (3). Rio de Janeiro: EdUERJ, 2002. p.83-131.

CANCLINI, N. G. Culturas Híbridas: estratégias para entrar e sair da modernidade. São Paulo: EdUSP, 2008. 4 v.

CARVALHO MELO, K.; SOUSA, R. E. M. Antropofagia pós-moderna - os Paiter Suruí e as tecnologias do século XXI. In: XI ENCONTRO NACIONAL DA ANPEGE, 11., 2015, Porto Alegre. Anais eletrônicos... Porto Alegre: ANPEGE/UFRGS, 2015. Disponível em <http://www.enanpege.ggf.br/2015/anais/arquivos/21/572.pdf>. Acesso em: 22 de novembro de 2018.

CARVALHO MELO, K.; ALMEIDA SILVA, A. Os Paiterey e a tecnologia: antropofagia pós-moderna. Revista Percurso - NEMO, Maringá v. 8, n. 1, p. 149 - 166, 2016. Disponível em < http://periodicos.uem.br/ojs/index.php/Percurso/article/view/31215/16870>. Acesso em: 21 de novembro de 2018.

CASSIRER, E. Antropología Filosófica: Introdução a uma filosofia de la cultura. México: Fondo de Cultura Económica, 1968. 5 v.

CASTELLS, M. O poder da identidade. Rio de Janeiro: Paz e Terra, 2002.

CLAVAL, P. A geografia cultural. Florianópolis: UFSC, 2007. 3 v.

DARDEL, E. O Homem e a Terra: natureza da realidade geográfica. São Paulo: Perspectiva, 2011.

DIEGUES, A. C. O mito moderno da natureza intocada. São Paulo: HUCITEC, 2001.

GIL, A. C. Métodos e Técnicas de Pesquisa Social. São Paulo: Atlas, 2008. 6 v.

HAESBAERT, R. O mito da desterritorialização: do "fim dos territórios" à multiterritorialidade. Rio de janeiro: Bertrand Brasil, 2004. 3 v.

HAVERROTH, M. Kaingang, um estudo etnobotânico: o uso e a classificação das plantas na Área Indígena Xapecó (oeste de SC). 1997, 175 f. Dissertação (Mestrado em Antropologia Social) Florianópolis: UFSC, 1997.

HOBSBAWM, E.; RANGER, T. A invenção das tradições. Rio de Janeiro: Paz e Terra, 1997. 2 v. Tradução de: Celina Cardim Cavalcante.

MARQUES, M. I. M. O modo de vida camponês sertanejo e sua territorialidade no tempo das grandes fazendas e nos dias de hoje em Ribeira-PB. Dissertação (Mestrado em Geografia) - São Paulo: USP, 1994.

MORIN, E. Meus Demônios. Rio de Janeiro: Bertrand Brasil, 1997.

MOTA. L. T.; NOVAK, É. S. Os Kaingang do vale do rio Ivaí: história e relações interculturais. Maringá: EdUEM, 2008.

SACK, R. D. Human territoriality: Theory and History. Cambridge: Cambridge University Press, 1986.

SANTOS, M. Técnica, espaço, tempo: globalização e meio técnico-científico-informacional. São Paulo: EdUSP, 2008.

SPIVAK, G. C. Pode o Subalterno Falar? Belo Horizonte: EdUFMG, 2010.

TOMMASINO, K. A ecologia dos Kaingang da bacia do rio Tibagi. In: MEDRI, M. E.; BIANCHINI, E.; SHIBATTA, O. A.; PIMENTA, J. A. (Orgs.). A bacia do rio Tibagi. Londrina:

UEL/KLABIN/FUNDAÇÃO ARAUCÁRIA/SERCOMTEL/CONFEPAR, 2002. p. 81-98. 
TUAN, Y. F. Topofilia: um estudo da percepção, atitudes e valores do meio ambiente. São Paulo: DIFEL, 1980. Tradução de: Lívia de Oliveira.

VEIGA, J. Aspectos fundamentais da cultura Kaingang. Campinas: Curt Nimuendajú, 2006.

Recebido em: 22/11/2017

Aceito para publicação em: 29/11/2018 